\title{
Trust and Credibility in Governing China's Risk Society
}

\author{
Guizhen He, ${ }^{\dagger}$ Arthur P. J. Mol, ${ }^{\ddagger}$ and Yonglong $\mathrm{Lu}^{\dagger} * *$ \\ ${ }^{\dagger}$ State Key Laboratory of Urban and Regional Ecology, Research Centre for Eco-Environmental Sciences, Chinese Academy of \\ Sciences, Beijing 100085, P.R. China \\ ${ }^{\ddagger}$ Environmental Policy Group, Wageningen University, Hollandseweg 1, $6706 \mathrm{KN}$, Wageningen, The Netherlands
}

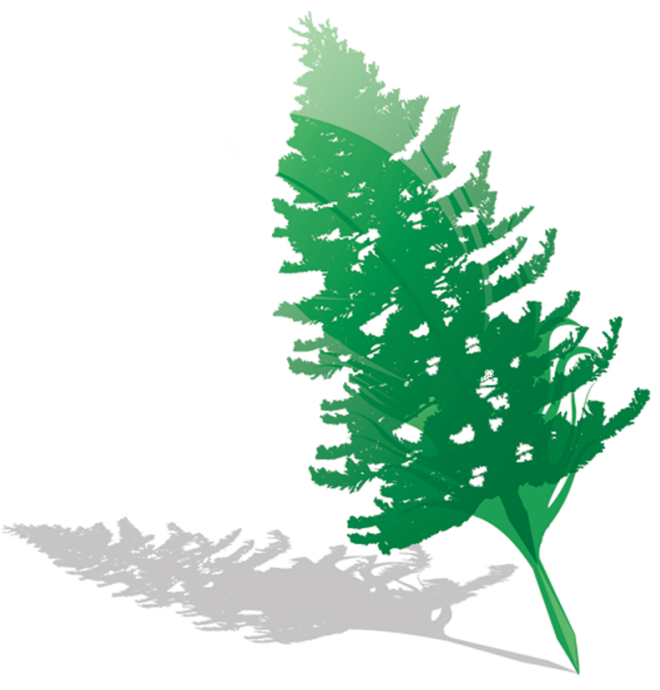

C hina's modernization process is characterized by technological advancement, profit-oriented economic development, a consumer society, and global integration. But this modernization process comes together with severe environmental risks. Accompanied by an average annual GDP growth of $10 \%$ from 1978 to 2011 , China has witnessed an ongoing stream of chemical spills, algal blooms, blood lead accidents, oil spills, food poisonings, flash floods, and sandstorms over the last decades. Over 33000 environmental accidents were counted between 1991 and 2010. ${ }^{1}$ As such China can be characterized as a risk society, and environmental risks are very visible in China's risk profile. Despite accelerating efforts by governmental environmental agencies at national and local levels to manage these risks, the situation has hardly improved since the mid 1990s. ${ }^{2}$

This perseverance of environmental risks and accidents and the widely perceived incapability of the Chinese government to effectively address these risks and accidents have contributed to an increased lack of trust and credibility in environmental authorities among the Chinese public. This lack of trust and credibility is noticeable beyond the area of environmental risks, and seems to have become a general phenomenon in contemporary Chinese society. Credibility and trust have become widely discussed among the public recently as governments are accused to have failed in coping with increasing fraud, fake products, improper academic behavior, illegal land transactions and pollutions, and disfunctioning civil services. ${ }^{3}$ A survey on "credibility of Chinese people" showed that the aggregate credibility index has remained stable at a low level. ${ }^{4}$ And many of the more than 180000 annual "mass incidents" are related to a lack of trust and credibility in local governments and the prevailing economic system. This even reached the Chinese leaders, who identified that two major problems - credibility in economy and society and public trust in the government-is hindering the economic and social progress of China. In October 2011 the Central Committee of the Communist Party of China approved a decision to develop a nation-wide credibility system, and the 12th Five-Year Plan period (2011-2015) will be used to establish it, with regulations, a credibility information system, credibility rating agencies, and promotional campaigns to enhance credibility.

One of root causes behind poor environmental risk management, and the related credibility-and-trust crisis, is the rapid transition to a high-speed market-oriented development model without having credible institutions in place that counter the side-effects of such a market-oriented development model. Market institutions are not oriented to manage environmental risk, the current hierarchical command-and-control system of environmental rules and authorities fails to do so, and there are no strong civil society institutions to push for environmental risk reduction.

In order to rebuild credibility and trust in environmental risks China needs to put trusted institutions in place that succeed in coping with environmental side-effects. Hence, China is currently undertaking a number of "real world experiments" to design and implement new institutions that can cope with the complex problems of high environmental risks, low trust and lack of credibility.

First, within the government arena a number of new institutions are being developed to cope with problems of credibility and trust. Strengthening enforcement of environmental laws and policies, especially at the local level, is enhanced through separation of duties and responsibilities, larger resources for monitoring and legal action, incentivizing citizens to tip law enforcers, establishing environmental courts, and having binding environmental targets included in annual responsibility contracts for local officials and mayors. Through these new arrangements environmental credibility and trust is meant to improve, and environmental quality better safeguarded.

Second, new market institutions are designed and implemented that aim to bring more credibility and trust by directing economic actors to more environmentally sound behavior. The (mandatory) introduction of Environmental Pollution Liability Insurance for major polluting companies will force environmentally sensitive industries to be ensured against

Received: June 18, 2012

Accepted: June 19, 2012

Published: June 27, 2012 
accidents, while insurance companies will incentivize these polluters into better performance and ensure compensation of pollution victims. Environmental conditionality for credit provisioning by banks attempts to build environmental credibility in new economic investments. Introducing environmental labels has been another attempt to build trust and credibility in products, but to a large extent in vain. The lack of independent auditing, cheating with labels, and food scandals with labeled products have strongly undermined trust in this market institution.

Third, Chinese authorities aim to build trust and credibility through larger openness, transparency and public access to environmental information. In 2008, the central government passed regulations to force governmental authorities and serious industrial polluters to disclose their environmental information to the public, and to allow civil organizations and the public to request for this environmental information. It is a promising initiative, although there is still a major gap between expectations and reality. ${ }^{5}$ Media reporting on environmental misbehavior is encouraged and environmental nongovernmental organizations (NGOs) are provided more freedom to report on that, also through Internet sites.

Fourth, participation has been given more leeway, to enhance credibility and trust. Enlarged possibilities to establish environmental NGOs, establishment of and better accessibility to complaint systems, more press freedom to report on environmental misbehavior and environmental protests, introduction of public hearings, and more involvement of citizens in environmental decision-making (such as around environmental impact assessments, drinking water pricing, payment for environmental services systems) make that the environmental field is leading in experiments with new participatory arrangements. The Internet and social media help in changing environmental victims, individuals and NGOs from passive information consumers into active information providers and even cogovernors. However, official policies and institutional arrangements on information disclosure, participation, protest and media reporting are more than incidentally overruled, especially by local governments and major economic interests.

These new institutions aim to build credibility and trust by coping in a more effective, transparent and participatory way with environmental risks. If successful, they might very well set the scene for the future national credibility system for the entire Chinese society.

\section{AUTHOR INFORMATION}

\section{Corresponding Author}

*E-mail: yllu@rcees.ac.cn.

\section{Notes}

The authors declare no competing financial interest.

\section{ACKNOWLEDGMENTS}

This study was supported by Natural Science Foundation of China (41071355), The Netherlands Royal Academy of Arts and Sciences and the Chinese Academy of Sciences (10CDP030).

\section{REFERENCES}

(1) Ministry of Environmental Protection. China Environment Yearbook 1991-2011; China Environmental Science Press: Beijing, 1992-2012; (in Chinese);
(2) He, G. Z.; Zhang, L.; Lu, Y. L.; Mol, A. P. J. Managing major chemical accidents in China: Towards effective risk information. J. Hazard. Mater. 2011, 187, 171-181.

(3) China Weekly. China's Crisis of Confidence: Why Can't We Trust? http://biz.cb.com.cn/12716612/20111118/300690.html (in Chinese, accessed May 15 2012).

(4) Ouyang, H. Y. Survey on credibility of the Chinese. Xiao Kang 2011, 8, 48-58 (in Chinese).

(5) Mol, A. P. J.; He, G. Z.; Zhang, L. Information disclosure in environmental risk management: Developments in China. J. Curr. Chin. Affairs 2011, 40 (3), 163-192. 